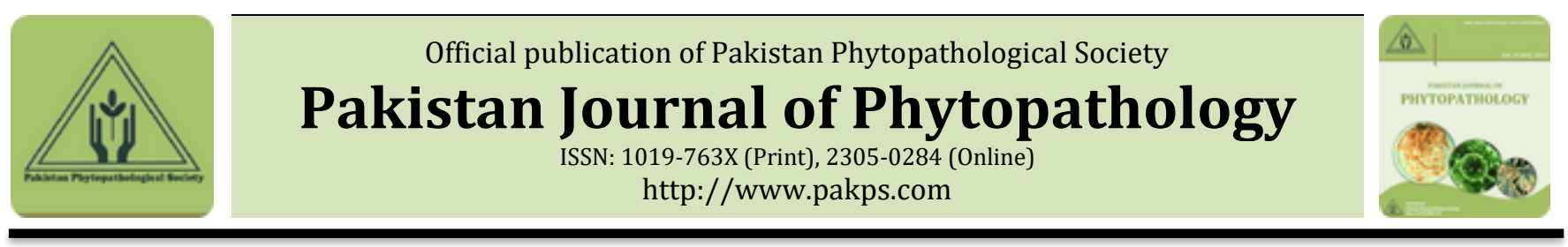

\title{
EFFECT OF SEED BIO PRIMING WITH RHIZOBACTERIA AGAINST ROOT ASSOCIATED PATHOGENIC FUNGI IN CHICKPEA
}

\author{
aMuhammad Sufyan, bMuhammad I. Tahir, bMuhammad I. U. Haq, cShabir Hussain, dMuhammad Saeed \\ a Crop Disease Research Institute Murree, National Agricultural Research Centre, Islamabad, Pakistan. \\ b Department of Plant Pathology, Pir Mehr Ali Shah Arid Agriculture University Rawalpindi, Pakistan. \\ c Department of Agronomy, Bahauddin Zakariya University, Multan, Pakistan. \\ d Wheat Research Sub-station, Murree, Ayub Agricultural Research Institute, Faisalabad, Pakistan.
}

\begin{abstract}
A B S T R A C T
Chickpea (Cicer arietinum L.) among other pulse legumes contribute majorly in economy of a country. Yield and quality of the produce is seriously affected by various soil borne pathogens whereas now-a-days use of PGPR as a substitute to chemicals is very effective. Chickpea desi variety (Bittal-98) was primed by hydrobio priming and drum priming methods using two rhizobacterial isolates i.e. Pseudomonas putida and Pseudomonas fluorescens. Both methods showed effective disease control i.e. drum priming (27.16\%) and hydro-biopriming (30.5\%) and improved growth parameters. The maximum shoot length was observed in drum priming $\mathrm{T}_{3}(22.40 \mathrm{~cm})$ as compared to control $(7.88 \mathrm{~cm})$. The root length also varied significantly, and the result ranged from $3.78 \mathrm{~cm}(\mathrm{Control})$ to $12.58 \mathrm{~cm}(\mathrm{~T} 3 \mathrm{Drum}$ priming). Similarly plants fresh weight $(0.91 \mathrm{gm})$ and plants dry weight $(0.63 \mathrm{gm})$ also considerably enhanced by drum priming in comparison with control $(0.43 \mathrm{gm}$ and $0.27 \mathrm{gm}$, respectively). The most effective treatment was when both rhizobacteria were applied together i.e. $\mathrm{T}_{3}$ thus resonating the effect of each other.
\end{abstract}

Keywords: PGPR, biopriming, root fungi, chickpea.

\section{INTRODUCTION}

Chickpea (Cicer arietinum L.) belongs to family fabaceae ranked third as major legume crop worldwide (Jukanti et al., 2012). In Pakistan the total area under chickpea production is about 944 thousand ha with the production of 438 thousand tones during 2018-2019 (Pakistan Bureau of Statistics, 2018-19). Chickpea crop is attacked by numerous pathogens which results in the yield reduction. Among the soil pathogens Macrophomina phaseolina (Kumar et al., 2007) and F. oxysporum f. sp. ciceris are of significant importance results in 10-40\% economic losses (Bayraktar and Dolar, 2009). Non-judicial use of fungicides results into resistance development in pathogens and also pollutes

Submitted: April 17, 2020

Revised: June 21, 2020

Accepted for Publication: July 02, 2020

* Corresponding Author:

Email: sufyan.razzaq21@gmail.com

(C) 2020 Pak. J. Phytopathol. All rights reserved. the environment. Naturally occurring beneficial microbes in root zone counter fight with the pathogens to prevent the yield losses. A thin soil layer occupied by the PGPR surrounding plants root system not only helping the plants root system to uptake maximum available nutrients to enhance the growth parameters but also by colonizing onto the root surface protect plants from numerous soil borne pathogens (Maleki et al., 2010; Moeinzadeh et al., 2010). PGPR triggers the defense mechanisms of the host like volatile compound Hydrogen cyanide (HCN), phytohormones (Kaur et al., 2006), siderophores (Rashid and Ahmed, 2005) and IAA, induced systemic resistance (ISR) (Suzuki et al., 2003) when any pathogen attack on host. Use of PGPR as a substitute to the chemicals for seed priming is very effective method to transfer bio-control agents not only in the rhizosphere but also effectively colonized onto the root surface of the plants (Bennett and Whipps, 2008). A number of methods adopted for the seeds priming such as Hydro priming, steep priming (Halmer et al., 2004), 
solid matrix priming and drum priming (Caseiro et al., 2004). The bio-priming techniques changes physiological behavior of the host under stress moreover significantly plays vital role to improve seeds tolerance level under environmental stress conditions (Entesari et al., 2013). In wheat, maize, chickpea and rice crop under semi-arid conditions seed bio-priming techniques found very useful to increase the yield (Harris et al., 2001). Seed bio-priming with PGPR before seed sowing provide first line of defense against pathogens and considerably enhanced the growth parameters (Halmer et al., 2004). In present study biopriming of chickpea seeds was done not only to test the efficacy of rhizobacteria as disease suppressing agent but also as plants growth promoting agents.

\section{MATERIALS AND METHODS}

Preparation of fungal pathogens: The culture of root associated pathogenic fungi (F. oxysporum f. sp. ciceris) was obtained from Department of Plant Pathology, PMAS-Arid Agriculture University Rawalpindi. The pathogenic culture was revived on potato dextrose agar (PDA) media and by following single hyphal tip method pure culture was maintained. Pathogenicity test was performed to confirm the disease causing ability of the fungus and after the confirmation of pathogenicity the fungus was mass cultured for further study.

Preparation of rhizobacteria: The bio-control agents Pseudomonas putida and Pseudomonas fluorescens were taken from the culture collection section of Department of Plant Pathology, PMAS-Arid Agriculture University Rawalpindi. The bacterial cultures were maintained in King's B broth.

Evaluation of rhizobacterial properties: To evaluate the rhizobacterial properties of bacterial isolates biochemical tests including Gram staining, $\mathrm{KOH}$ Loop test (Suslow, 1982), catalase oxidase test (Schaad, 1980), antagonistic test and siderophore production test were performed and the results of these biochemical tests clearly showed the rhizobacterial nature of the cultures.

The result of gram staining showed that both of the isolates were gram negative in nature. Loop formation was observed in both isolates which confirmed staining results in $\mathrm{KOH}$ test. Similarly, catalase oxidase test confirmed the aerobic nature of the bacteria when treated to $\mathrm{H}_{2} \mathrm{O}_{2}$ both formed gas bubbles. Siderophore production of bacteria was identified by the production of fluorescent pigment. Low iron media have high iron $\left(\mathrm{Fe}^{+3}\right)$ chelator affinity (Calinski et al., 1981). Both bacterial isolates were found positive for siderophore production. The color was diffused into the medium around the colony. The isolates produced yellow to greenish color. To check the antifungal activity of the bacterial isolates dual culture test was performed by using PDA media and after $72 \mathrm{~h}$ of incubation the zone of inhibition clearly illustrates the antifungal nature of the bacterial isolates.

Bacterial culture preparation: The antagonistic rhizobacterial isolates were inoculated to King's B broth media and incubated on shaker incubator at $28^{\circ} \mathrm{C}$ for 48 hours. The antagonistic rhizobacterial isolates were suspended in 1\% Carboxy Methyl Cellulose solution to attain $10^{8} \mathrm{CFU} \mathrm{mL}^{-1}$ measured by spectrophotometer (Tahir et al., 2016).

$\mathrm{C}=$ Control + F. oxysporum f.sp. ciceris

$\mathrm{T}_{1}=$ P. putida + F. oxysporum f.sp. ciceris

$\mathrm{T}_{2}=$ P. fluorescens $+F$. oxysporum f.sp. ciceris

$\mathrm{T}_{3}=$ P. putida + P. fluorescens $+F$. oxysporum f.sp. ciceris

Biopriming of Chickpea Seeds: Two techniques were applied for bio-priming of chickpea seeds

Hydro Bio Priming: Chickpea seeds of desi variety (Bittal-98) were surface sterilized with $1 \%$ solution of sodium hypochlorite for 2-3 minutes approximately followed by washing 2-3 times with distilled water. First for 1 hour the chickpea seeds were soaked in water followed by 2 hours in PGPR suspension than left at room temperature for air drying and finally in moist chamber for 24 hours. Chickpea seeds only treated with Carboxy Methyl Cellulose (CMC) sown as control.

Drum Priming: Chickpea seeds of desi variety (Bittal98) were surface sterilized with $1 \%$ solution of sodium hypochlorite for 2-3 minutes approximately followed by washing 2-3 times with distilled water. The seeds of chickpea were bio-primed with PGPR suspension for 2-3 hours in a rotating drum than left at room temperature for air drying and finally in moist chamber for 24 hours. Chickpea seeds only treated with Carboxy Methyl Cellulose (CMC) sown as control.

Data Collection and statistical analysis: Three replications of each treatment were maintained. After 42 days the parameters included seed germination, disease incidence, shoot length, root length, plant fresh weight, and plant dry weight were recorded. The data was statistically analyzed using statistix ( $\mathrm{V}$ 8.0). The treatment means were compared by ANOVA and the least significance difference test was applied for checking the significance of values $(\mathrm{P} \geq 0.05)$. 


\section{RESULTS}

Disease Incidence: Diseases incidence was recorded by following formula

Disease incidence (\%)

$$
=\frac{\text { Number of infected plants }}{\text { Total number of plants }} \times 100
$$

Disease incidence: The PGPR isolates considerably control the disease in comparison with control (Figure 1). Minimum disease incidence was observed in $\mathrm{T}_{3}$ with drum priming $(27.16 \%)$ followed by $30.5 \%\left(\mathrm{~T}_{3}\right)$ hydrobiopriming. Results showed the effectiveness of PGPR isolates to control the disease.

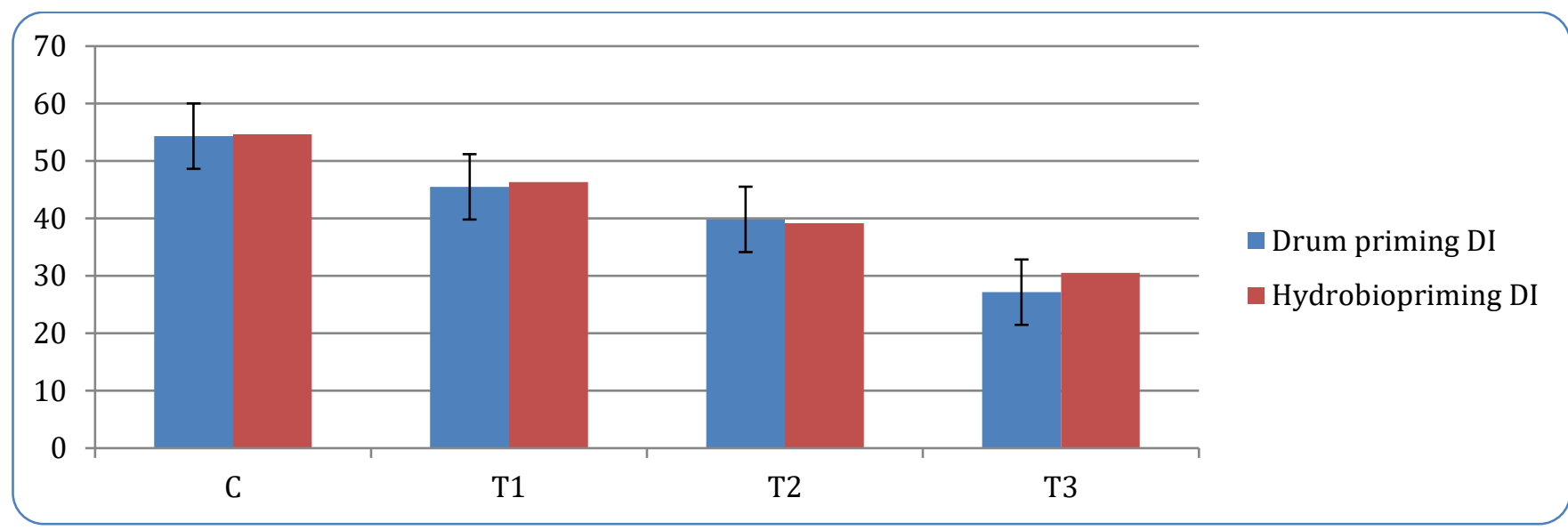

Figure 1. Disease Incidence on chickpea plants treated with rhizobacteria using drum priming and hydro biopriming method.

\section{Growth parameters}

Seed germination: Germination percentage was calculated by using following formula.

$$
=\frac{\begin{array}{c}
\text { Seed Germination (\%) } \\
\text { Number of seeds germinated }
\end{array}}{\text { Total number of seeds sown }} \times 100
$$

Shoot and Root length: To check the effect of PGPR on the growth of plants shoot and root system the chickpea plants were carefully uprooted after 6th week and the data of plants shoot length and root length were measured in centimeters $(\mathrm{cm})$. The positive influence of PGPR was clearly observed by comparing PGPR treated plants with control.

Seed Germination: PGPR treated and untreated chickpea seeds showed very clear difference in germination percentage of seeds. Minimum seeds germination was recorded in control, whereas maximum seeds germination was observed in $\mathrm{T}_{3}$ with drum priming. $\mathrm{T}_{1}$ and $\mathrm{T}_{2}$ also show promising outcomes in comparison with control (Figure 2).

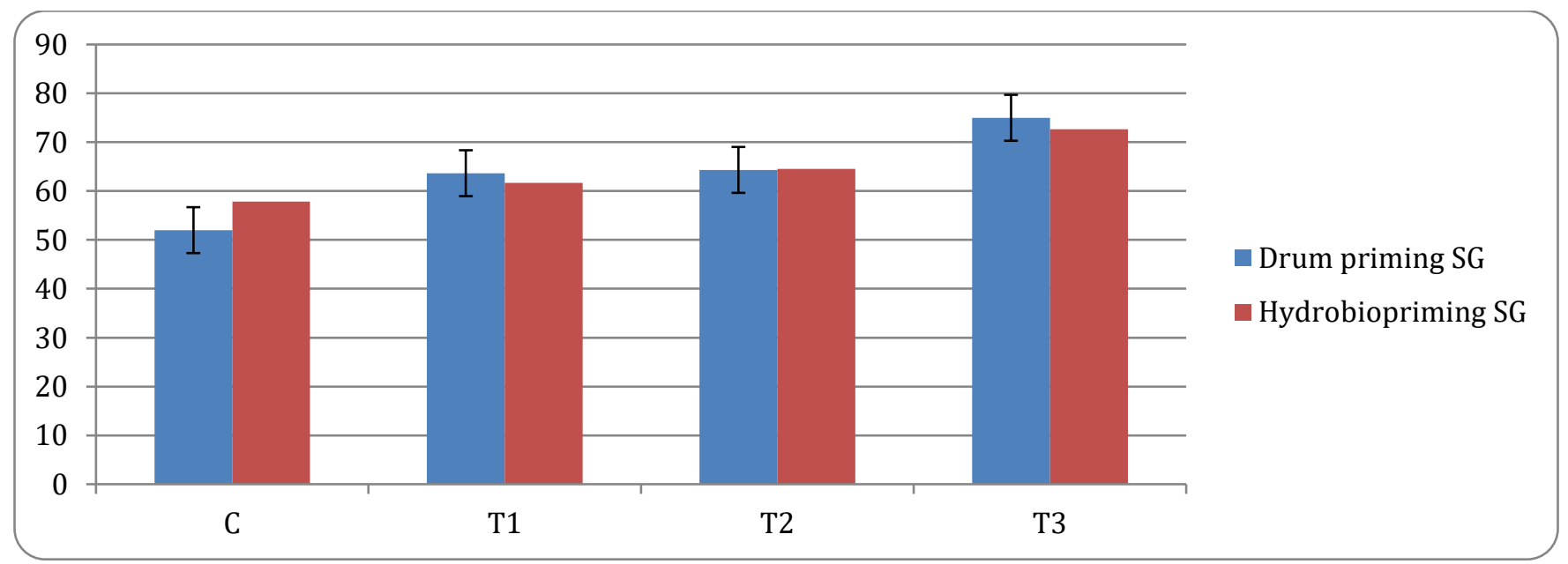

Figure 2. Germination of chickpea seeds treated with rhizobacteria using drum priming and hydro biopriming method. 
Shoot length: The PGPR isolates significantly improve the plants shoot length (Figure 3). Outcomes illustrate that shoot length significantly enhanced in PGPR treated plants over untreated plants. The maximum shoot length $(22.40 \mathrm{~cm})$ was observed in $\mathrm{T}_{3}$ with drum priming method whereas $\mathrm{T}_{3}$ with Hydro-biopriming $(20.01 \mathrm{~cm})$.

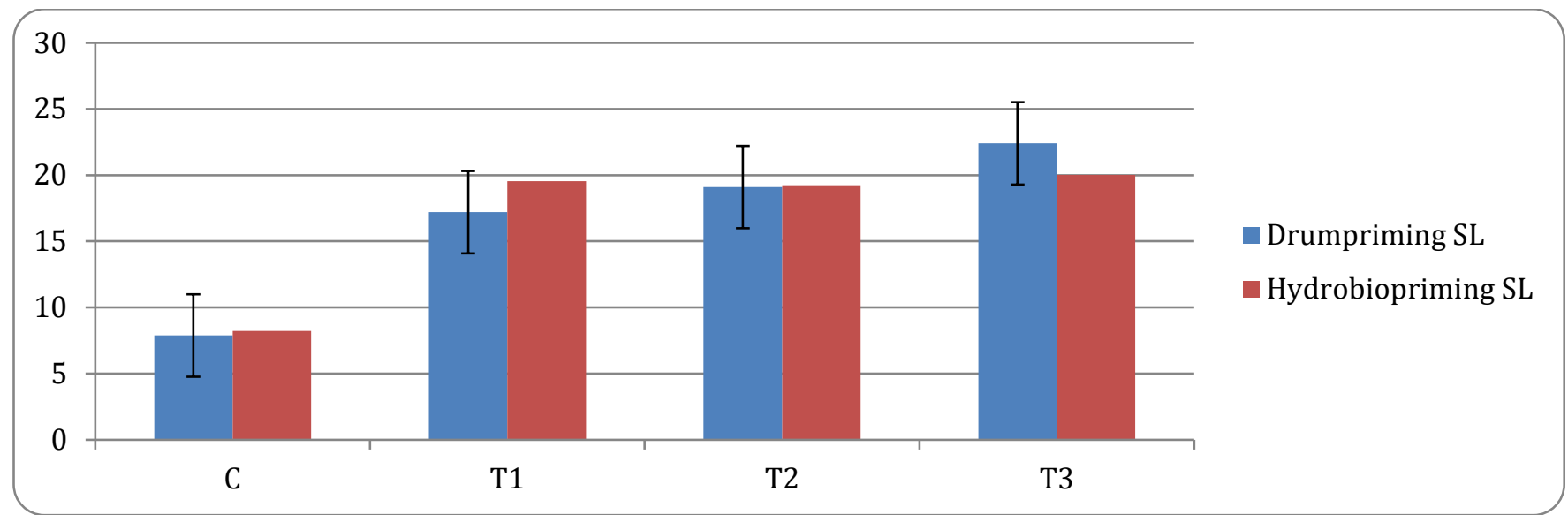

Figure 3. Shoot length of chickpea plants treated with rhizobacteria using drum priming and hydro biopriming method.

Root length: The PGPR isolates considerably enlarged the root length of the treated plants (Figure 4). The length of the roots ranges from 3.78 to $12.58 \mathrm{~cm}$. $\mathrm{T}_{3}$ (Drum priming) produced the maximum root length
$12.58 \mathrm{~cm}$ followed by $\mathrm{T}_{3}$ (Hydro biopriming) $11.15 \mathrm{~cm}$. In comparison with control $\mathrm{T}_{1}(9.25 \mathrm{~cm}), \mathrm{T}_{2}(10.56 \mathrm{~cm})$ (Drum priming) and $\mathrm{T}_{1}(9.03 \mathrm{~cm})$ (Hydro biopriming) also significantly enhance the root length of the plants.

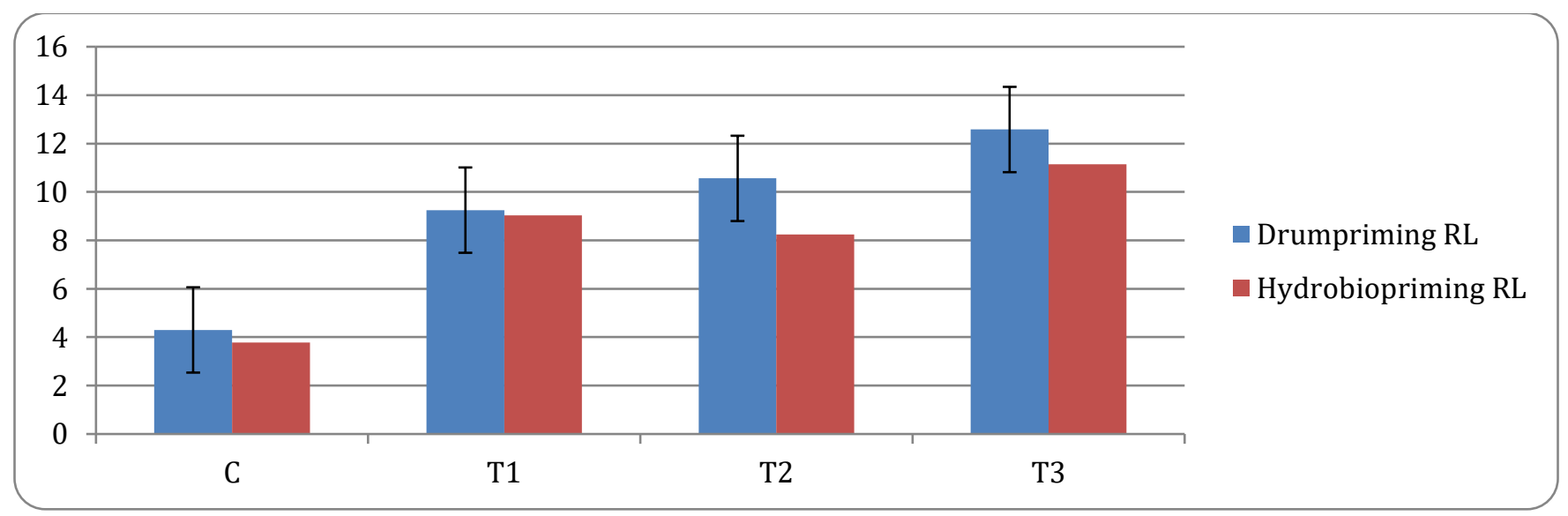

Figure 4. Root length of chickpea plants treated with rhizobacteria using drum priming and hydro biopriming method.

Plant Fresh Weight: The PGPR isolates plays a vital role in enhancing the plants fresh weight. As for as both methods are concerned drum priming again showed best results in comparison with hydro-bio priming and control. Treatment $\mathrm{T}_{3} 0.91 \mathrm{gm}$ (drum priming) showed promising outcomes as compared to the rest of the treatments (Figure 5).

Plant Dry Weight: A considerable difference in chickpea plants dry weight was observed in response to PGPR isolates (Figure 6). The minimum plants dry weight was noticed in control $(0.27 \mathrm{gm})$ with hydro bio-priming method, whereas maximum plants dry weight was observed in $\mathrm{T}_{3}(0.63 \mathrm{gm})$ followed by $\mathrm{T}_{2}(0.54 \mathrm{gm})$ with drum priming.

Total biomass: The accumulation of total biomass of PGPR treated plants increased significantly in both methods as compared to control. Treatment $\mathrm{T}_{3}$ (Drum priming) showed best outcomes followed by treatment $\mathrm{T}_{3}$ (Hydro biopriming), $\mathrm{T}_{2}$ (Drum priming) and $\mathrm{T}_{1}$ (Drum priming) (Figure 7). 


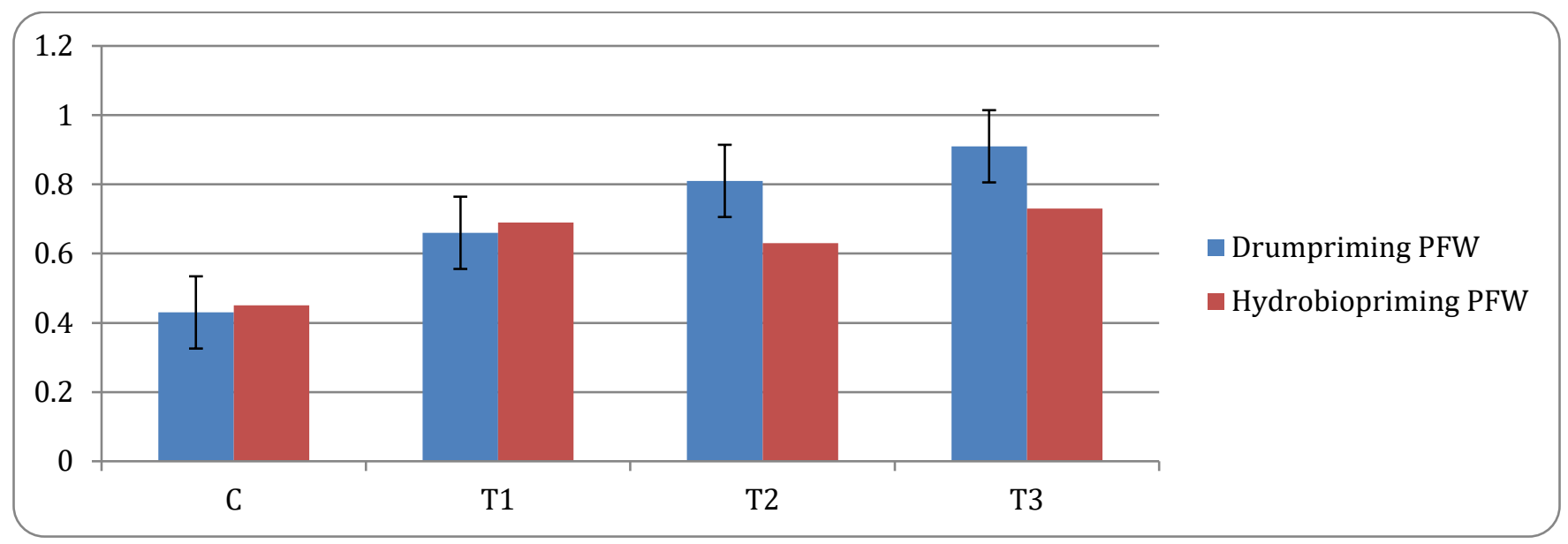

Figure 5. Plants fresh weight of chickpea plants treated with rhizobacteria using drum priming and hydro biopriming method.

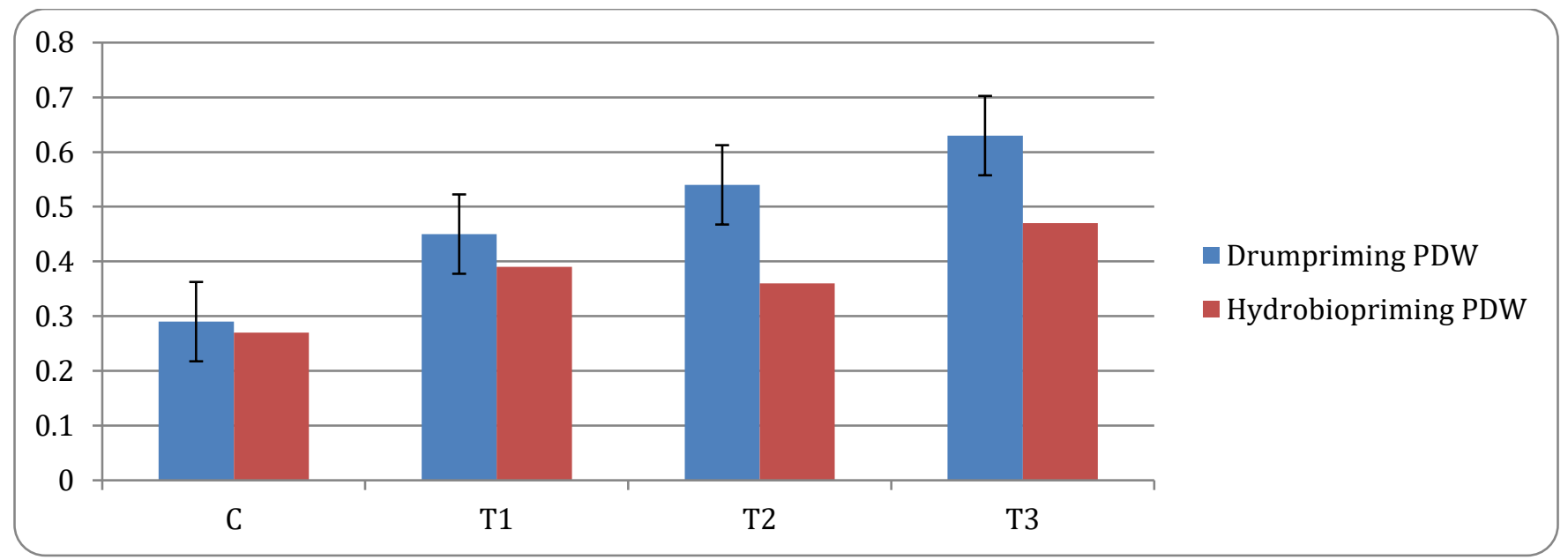

Figure 6. Dry weight of chickpea plants treated with rhizobacteria using drum priming and hydro biopriming method.

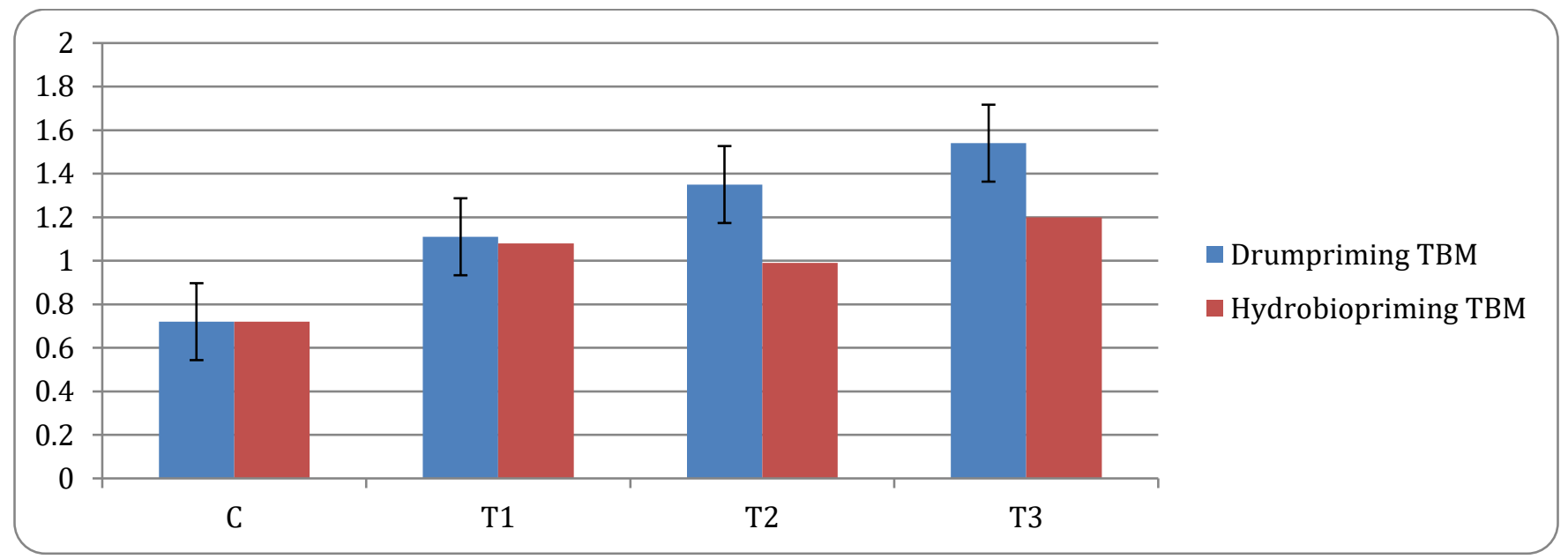

Figure 7. Total biomass of chickpea plants treated with rhizobacteria using drum priming and hydro biopriming method. 


\section{DISCUSSION}

The growth of the plants has been significantly enhanced by various rhizobacterial strains (Raj et al., 2004; Beneduzi et al., 2012). Plant growth promoting rhizobacteria (PGPR) not only plays vital role in disease suppression but also shows the ability to colonize and helps roots system of plants to obtain maximum available nutrients (Frankenberger and Arshad, 1995). The basic aim of the current study was to select the suitable rhizobacterial strain that enhanced resistant against pathogens and improve growth parameters of plants. Many seed priming methods including solid-matrix priming and hydropriming were reported to improve the growth parameters (Venkatasubramanian and Umarani, 2007). Plant growth promoting rhizobacteria uniformly distributed on the seeds surface by biopriming techniques, similar research work illustrated the efficient role of bio-priming methods (Moeinzadeh et al., 2010). As current work shows that both hydrobio priming technique and drum priming technique improved the growth parameters like seed germination, shoot length, root length, fresh and dry weight of shoot and root as well as reduce the disease incidence. Drum priming method found more efficient to transfer the PGPR on seeds surface (Bennett and Whipps, 2008) same as the current research work exhibited that drum priming method performs better as compared to the other applied method. Improved seed germination rate in sunflower and wheat crop were reported by the use of PGPR (Shaukat et al., 2006) similar outcomes also reported by Dobbelaere et al. (2002) in spring wheat. The bio-priming of chickpea seeds with PGPR by using drum priming and hydro-bio priming shows same results as reported by Shaukat et al. (2006) and Dobbelaere et al. (2002). The conducted work showed that priming with PGPR not only improved the total biomass of the plants but also reduced the disease incidence as compared to control. The finding was similar to the outcomes of Erdogan and Benlioglu (2010). Shoot and root length of chickpea plants considerably improved by using PGPR and same results were reported earlier by Kamal et al. (2008). On treating seeds with the PGPR the radical emergence is greatly influenced as PGPR invade root system of seedling plants via germinating radical (Park et al., 2004). The PGPR application to the seeds by any means like bio-priming methods, seeds dipping or sprays significantly enhanced the growth parameters and helps to control seed, soil and root associated pathogens (Nakkeeran et al.). As compared to the control the bio-priming of chickpea with PGPR showed less disease incidence with significant improvement in growth parameters as reported by (Mancini and Romanazzi, 2014). The use of PGPR is environment friendly and helps to reduce the need of pesticides as well.

\section{CONCLUSION}

The application of chemicals for seed treatment poses hazards to environment and this study has highlighted the possible alternative to synthetic chemicals. Seeds can be treated with PGPRs that can be beneficial in several ways i.e. by inhibiting pathogens as well as providing compounds that promote plant growth at the same time. It is further recommended that priming methods be explored and tested for improved results.

\section{REFRENCES}

Bayraktar, H. and F. S. Dolar. 2009. Genetic Diversity of Wilt and Root Rot Pathogens of Chickpea, as Assessed by RAPD and ISSR. Turk. J. Agric. Res. 33: 1-10.

Beneduzi, A., A. Ambrosini and L. M. Passaglia. 2012. Plant growth-promoting rhizobacteria (PGPR): Their potential as antagonists and biocontrol agents. Genetics and Molecular Biology, 35: 104451.

Bennett, A. J. and J. M. Whipps. 2008. Dual application of beneficial microorganisms to seed during drum priming. Applied Soil Ecology, 38: 83-89.

Calinski, T., R. G. D. Steel and J. H. Torrie. 1981. Principles and Procedures of Statistics: A Biometrical Approach. Biometrics, 37: 859.

Caseiro, R., M. A. Bennett and J. Marcos-Filho. 2004. Comparison of three priming techniques for onion seed lots differing in initial seed quality. Seed Science and Technology, 32: 365-75.

Dobbelaere, S., A. Croonenborghs, A. Thys, D. Ptacek, Y. Okon and J. Vanderleyden. 2002. Effect of inoculation with wild type Azospirillum brasilense and $A$. irakense strains on development and nitrogen uptake of spring wheat and grain maize. Biology and Fertility of Soils, 36: 284-97.

Entesari, M., F. Sharifzadeh, M. Ahmadzadeh and M. Farhangfar. 2013. Seed Biopriming with Trichoderma Species and Pseudomonas fluorescent on Growth Parameters, Enzymes Activity and 
Nutritional Status of Soybean. International Journal of Plant Production, 4: 610-19.

Erdogan, O. and K. Benlioglu. 2010. Biological control of Verticillium wilt on cotton by the use of fluorescent Pseudomonas spp. under field conditions. Biological Control, 53: 39-45.

Frankenberger, J. R. W. T. and M. Arshad. 1995. Phytohormones in soils. Microbial Production and Function Marcel Dekker, Inc. New York. pp. : 5-40.

Halmer, P., R. L. Benech-Arnold and R. A. Sa'nchez. 2004. Methods to improve seed performance in the field. (Eds.), Handbook of Seed Physiology Applications to Agriculture. The Haworth Press Inc., New York: 125-66.

Harris, D., B. S. Raghuwanshi, J. S. Gangwar, S. C. Singh, K. D. Joshi, A. Rashid and P. A. Hollington. 2001. Participatory Evaluation by Farmers of on-Farm Seed Priming in Wheat in India, Nepal and Pakistan. Experimental Agriculture, 37: 403-15.

Jukanti, A. K., P. M. Gaur, C. L. Gowda and R. N. Chibbar. 2012. Nutritional quality and health benefits of chickpea (Cicer arietinum L.): a review. Br J Nutr, 108 Suppl 1: S11-26.

Kamal, A. M., Abo-Elyousr, H. Hoda and El-Hendawy. 2008. Integration of Pseudomonas fluorescens and acibenzolar-Smethyl to control bacterial spot disease of tomato. . Crop Protection, 27: 1118-24.

Kaur, R., J. Macleod, W. Foley and M. Nayudu. 2006. Gluconic acid: an antifungal agent produced by Pseudomonas species in biological control of takeall. Phytochemistry, 67: 595-604.

Kumar, V., A. Kumar and R. N. Kharwar. 2007. Antagonistic potential of fluorescent pseudomonads and control of charcoal rot of chickpea caused by Macrophomina phaseolina. Journal of Environmental Biology, 28: 15-20.

Maleki, M., S. Mostafaee, L. Mokhtarnejad and M. Farzaneh. 2010. Characterization of Pseudomonas fluorescens strain CV6 isolated from cucumber rhizosphere inVaramin as a potential biocontrol agent. . Australian Journal of Crop Science, 4: 67683.

Mancini, V. and G. Romanazzi. 2014. Seed treatments to control seedborne fungal pathogens of vegetable crops. Pest Management Science, 70: 860-8.

Moeinzadeh, A., F. S. Zadeh, M. Ahmadzadeh and F. H. Tajabadi. 2010. Biopriming of sunflower (Helianthus annuus L.) seed with Pseudomonas fluorescens for improvement of seed invigoration and seedling growth. . Australian Journal of Crop Science, 4: 564-70.

Nakkeeran, S., W. G. D. Fernando and Z. A. Siddiqui. Plant Growth Promoting Rhizobacteria Formulations and its Scope in Commercialization for the Management of Pests and Diseases PGPR: Biocontrol and Biofertilization. Springer-Verlag. pp. 257-96.

Park, O., J. Kim, C.-M. Ryu and C.-S. Park. 2004. Colonization and Population Changes of a Biocontrol Agent, Paenibacillus polymyxa E681, in Seeds and Roots. The Plant Pathology Journal, 20: 97-102.

Raj, S. N., N. P. Shetty and H. S. Shetty. 2004. Seed biopriming withPseudomonas fluorescensisolates enhances growth of pearl millet plants and induces resistance against downy mildew. International Journal of Pest Management, 50: 4148.

Rashid, D. and B. Ahmed. 2005. Effect of iron and growth inhibitors on siderophores production by Pseudomonas fluorescens. African Journal of Biotechnology, 4: 697-702.

Schaad, N. W. 1980. Laboratory guide for the identification of plant pathogenic bacteria. American Phytopathological Society Saint Paul. Minnesota: 28-45.

Shaukat, K., S. Afrasayab and S. Hasnain. 2006. Growth Responses of Helianthus annus to Plant Growth Promoting Rhizobacteria used as a Biofertilizers. International Journal of Agricultural Research, 1: 573-81.

Suslow, T. V. 1982. Application of a Rapid Method for Gram Differentiation of Plant Pathogenic and Saprophytic Bacteria Without Staining. Phytopathology, 72: 917.

Suzuki, S., Y. He and H. Oyaizu. 2003. Indole-3-Acetic acid production in Pseudomonas fluorescens HP72 and its association with suppression of creeping bentgrass brown patch. Current Microbiology, 47: 138-43.

Tahir, M. I., M. Inam-ul-Haq, M. Ashfaq, N. A. Abbasi, H. Butt and H. Ghazal. 2016. Screening of effective antagonists from potato rhizosphere against bacterial wilt pathogen. International Journal of Biosciences, 8: 228-40. 
Venkatasubramanian, A. and R. Umarani. 2007. Evaluation of seed priming methods to improve seed performance of tomato (Lycoperison esculentum), egg plant (Solanum melongena) and chilli (Capsicum annum). Seed Science and Technology, 35: 487-93.

\begin{tabular}{|lrl}
\hline \multicolumn{2}{l}{ Contribution of Authors: } \\
Muhammad Sufyan & $:$ & Conceive research idea, designed and conduct experiment. \\
Muhammad I. Tahir & $:$ & Wrote manuscript. \\
Muhammad I. U. Haq & $:$ & Major research supervisor. \\
Shabir Hussain & $:$ & Helped in research design and data interpretation. \\
Muhammad Saeed & $:$ & Helped in writing manuscript. \\
\hline
\end{tabular}

